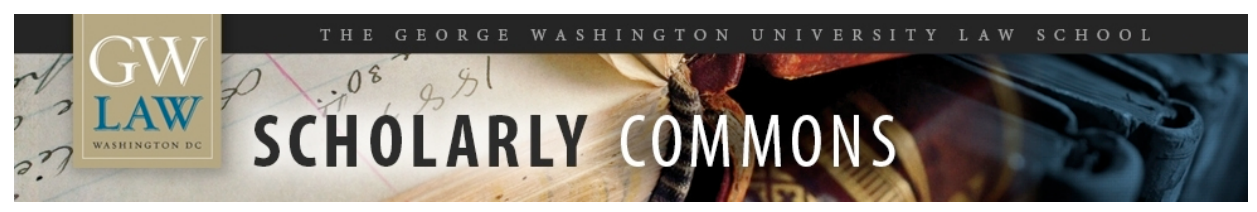

\title{
Facilitating Scientific Research: Intellectual Property Rights and the Norms of Science - A Response to Rai and Eisenberg
}

\author{
F. Scott Kieff \\ George Washington University Law School, skieff@law.gwu.edu
}

Follow this and additional works at: https://scholarship.law.gwu.edu/faculty_publications

Part of the Law Commons

\section{Recommended Citation}

F. Scott Kieff, Facilitating Scientific Research: Intellectual Property Rights and the Norms of Science - A Response to Rai and Eisenberg, 95 Nw. U. L. Rev. 691 (2001).

This Article is brought to you for free and open access by the Faculty Scholarship at Scholarly Commons. It has been accepted for inclusion in GW Law Faculty Publications \& Other Works by an authorized administrator of Scholarly Commons. For more information, please contact spagel@law.gwu.edu. 


\title{
Forum
}

\section{FACILITATING SCIENTIFIC RESEARCH: INTELLECTUAL PROPERTY RIGHTS AND THE NORMS OF SCIENCE-A RESPONSE TO RAI AND EISENBERG}

\author{
F. Scott Kieff*
}

\section{INTRODUCTION}

Arti Rai's article in the Fall 1999 issue of the Northwestern University Law Review explores the proper use of both legal rules and prescriptive norms to shape behavior in the basic biological research community. ${ }^{1}$ Rai's article builds upon the extensive work in this area by Rebecca Eisenberg, which first attained prominence through Eisenberg's article in the December 1987 issue of the Yale Law Journal. ${ }^{2}$ Eisenberg concludes that the use of patents in the area of basic biological research may frustrate central

\footnotetext{
* Visiting Assistant Professor, Northwestern University School of Law. I gratefully acknowledge the many questions and comments on prior drafts from participants in seminars at Northwestern University's graduate schools of management, biology, journalism, medicine, and law, as well as more extensive discussions with Michael Abramowicz, Christopher Bracey, Richard Brooks, Rochelle Dreyfuss, Clint Francis, David Haddock, Leo Katz, Elliott Kieff, Elizabeth Kieff, Jacqueline Kieff, Jim Lindgren, Jerry Linn, Fred McChesney, Rob Merges, Pauline Newman, Ralph Oman, Giles Rich, Marshall Shapo, Henry Smith, and John Witherspoon. Please send correspondence to fskieff.91@alum.mit.edu (permanent address).

1 Arti Kaur Rai, Regulating Scientific Research: Intellectual Property Rights and the Norms of Science, 94 Nw. U. L. REV. 77 (1999).

2 Rebecca S. Eisenberg, Proprietary Rights and the Norms of Science in Biotechnology Research, 97 YALE. L.J. 177 (1987) (exploring the potential negative impact of patent rights on scientific norms in the field of basic biological research) [hereinafter Eisenberg, Proprietary Rights]; see also, e.g., Rebecca S. Eisenberg, Patents and the Progress of Science: Exclusive Rights and Experimental Use, 56 U. CHI. L. REV. 1017 (1989) [hereinafter Eisenberg, Progress of Science] (exploring an experimental use exemption from patent infringement as a device for alleviating potential negative impact of patent rights on scientific norms in the field of basic biological research); Rebecca S. Eisenberg, Public Research and Private Development: Patents and Technology Transfer in Government-Sponsored Research,82 VA. L. REV. 1663 (1996) (offering preliminary observations about the empirical record of the use of patents in the field of basic biological research and recommending a retreat from present government policies of promoting patents in that field); Michael A. Heller \& Rebecca S. Eisenberg, Can Patents Deter Innovation? The Anticommons in Biomedical Research,280 SCIENCE 698 (1998) (arguing that patents can deter innovation in the field of basic biological research).
} 
norms of the community. ${ }^{3}$ Rai prescribes concerted public and private action as the best tools for avoiding patents and the problems Eisenberg attributes to them. ${ }^{4}$ This Essay responds to patent critics like Rai and Eisenberg by showing how patents are essential for promoting the central norms of the basic biological research community.

Rai begins her argument by painting a portrait of the basic biological research community before 1980 as a benchmark against which to measure the relative performance of that same community today. She analyzes the traditional prescriptive norms of the earlier community and argues that they "discouraged property rights in scientific invention and discovery." Against this benchmark, she criticizes the shift in the statutory and case law around 1980 that increased availability of patents in this community. ${ }^{6}$ According to Rai, this legal change triggered a cascade of selfish behavior among those in the community that caused a significant erosion of the community's central norms, replacing them instead with property interests. 'Rai then provides an economic analysis to justify her argument that patents should be avoided in this community. ${ }^{8}$ In the end, Rai recommends the creation and implementation of new laws and prescriptive norms to avoid patents and the problems they purportedly cause for the basic biological research community. ${ }^{9}$

There are several problems with Rai's argument. First, Rai mischaracterizes the pre-1980 basic biological research community. The community's norms did not discourage intellectual property before 1980, or thereafter. Furthermore, her portrait does not account for the pernicious, selfish behavior that existed in this highly competitive and stratified community before 1980 and that persists today. In addition, Rai misinterprets the operation and design of the patent system. The shift in applicable patent law that took place around 1980 brought the system in line with normative legal theory and design. The shift marks a positive change because patents are essential for bringing needed resources to the community. This infusion of resources has two output-expanding effects on community performance. Some increased output is due simply to increased input. Some is due to improved efficiency. The added resources brought by patents can operate as important tools for overcoming the frustration of the community's prescriptive norms that would otherwise be caused by selfish behavior. Therefore, the use of patents in the basic biological research community should be encouraged.

\footnotetext{
${ }^{3}$ Eisenberg further recommends various avenues for retreating from strong patent enforcement. See sources cited supra note 2 .

${ }^{4}$ Rai, supra note 1 , at 152.

5 Id. at 88 .

${ }^{6}$ Id. at 115

7 Id.

8 Id. at 80 .

9 Id. at 152.
} 


\section{SetTing A PROPER BENCHMARK}

The norms of the basic biological research community that are the focus of arguments by patent critics like Rai and Eisenberg are termed "prescriptive norms," or "normative norms."10 These are "socially inculcated beliefs within the research science community about how scientists should behave, as opposed to descriptions of how they actually do behave." 11 These prescriptive norms of the basic biological research community closely track the traditional prescriptive norms of basic science as they are generally explored in the works of sociologists Barnard Barber, Warren Hagstrom, and Robert Merton. ${ }^{12}$ Eisenberg focuses on the following four interrelated prescriptive norms: universalism, communism, disinterestedness, and organized skepticism. ${ }^{13}$ Universalism means that the veracity of claimed scientific observations should be determined by universal criteria without regard to the particular attributes of the claimant, such as reputation, institutional affiliation, or nationality. ${ }^{14}$ Communism means that scientific advances should be a product of the community and for the benefit of the community. ${ }^{15}$ Disinterestedness means that scientific effort should be expended for the purpose of seeking generally applicable scientific truth, rather than some personal interest. ${ }^{16}$ Organized skepticism means that claimed scientific observations should be subject to empirical scrutiny. ${ }^{17}$

Rai expands the focus to include two additional prescriptive norms: independence and invention. ${ }^{18}$ Independence means that scientists should be "free to set their own research agendas and to criticize the work of others." 19 Invention means that scientists should "make original contributions to the common stock of knowledge.,"20

This set of prescriptive norms may be an accurate accounting of the consensus goals of the basic biological research community and a proper statement of what those goals should be. ${ }^{21}$ Nevertheless, each of these prescriptive norms is relatively abstract. Moreover, even as a set they fail to

10 Id. at 81; see also, e.g., Eisenberg, Proprietary Rights, supra note 2, at 179 n.5.

11 Eisenberg, Proprietary Rights, supra note 2, at 179 n.5.

12 See Bernard Barber, Science And the Social Order (1953); Warren O. Hagstrom, The SCIENTIFIC COMMUNITY (1965); ROBERT K. MERTON, T HE SOCIOLOGY OF SCIENCE (1973).

13 Eisenberg, Proprietary Rights, supra note 2, at 183 (citing MERTON, supra note 12, at 270-77).

14 Id. (citing MERTON, supra note 12, at 270-73).

15 Id. (citing MERTON, supra note 12, at 273-75).

16 Id. (citing MERTON, supra note 12, at 275-77).

17 Id. (citing MERTON, supra note 12, at 277).

18 Rai, supra note 1, at 90-94.

19 Id. at 91 (citing BARBER, supra note 12, at 89-90, 144 and HAGSTROM, supra note 12, at 88).

20 Id. at 92 (citing HAGSTROM, supra note 12, at 13, 23-42, 69-85). Eisenberg also discusses this norm, but she does so in a way that does not expressly identify it as a norm. Eisenberg, Proprietary Rights, supra note 2, at 183-84 (citing MERTON, supra note 12, at 286, 325-27).

21 For purposes of this Essay, the prescriptive norms discussed thus far are not disputed, and so for convenience are referred to collectively as the "consensus set" of prescriptive norms. 
give clear guidance about the merits of specific behaviors, like seeking patents. Rai asserts that before 1980 these prescriptive norms interacted in a way that "discouraged property rights in scientific invention and discovery." ${ }^{22}$ More specifically, Rai argues that in light of the prescriptive norm of communism, scientists in this community did not seek property rights in their inventions, but were instead rewarded merely with recognition and esteem. ${ }^{23}$ Thus, Rai essentially argues that there existed an additional, more specific, prescriptive norm directly targeted against the seeking of intellectual property, and that this additional prescriptive norm can be derived from the consensus set of more abstract prescriptive norms discussed above.

Yet, no such additional specific prescriptive norm against seeking intellectual property existed in the basic biological science community before 1980, or thereafter. Furthermore, to the extent that additional prescriptive norms about seeking patents or other forms of intellectual property can be derived from the consensus set of more abstract prescriptive norms, such a derivative prescriptive norm should not be directed against patents, as urged by Rai. A prescriptive norm in favor of patents will better promote the consensus set of more abstract prescriptive norms.

The pre-1980 basic biological research community did not have a prescriptive norm against seeking intellectual property. Rai's argument that scientists sought merely recognition and esteem rather than property ignores the ability for recognition and esteem to function as forms of property. It is well recognized that scientists generally have treated reports of a scientist's work as a form of intellectual property, serving as one type of currency in the market for scientific kudos. ${ }^{24}$ And scientists have demonstrated countless ingenious methods for staking out, defending, and even pirating this form of intellectual property. ${ }^{25}$ The persistence and prevalence of this form of intellectual property in the scientific community strongly suggests that its use was at least countenanced, if not encouraged, by applicable prescriptive norms. ${ }^{26}$

It is not even clear that the pre-1980 basic biological research community had a prescriptive norm that specifically rejected patents, as distinct from other forms of intellectual property. In arguing that the presentlyobserved desire for patents in the basic biological research community was sparked by a change in applicable patent law, Rai presumes that there was a lack of desire for patents before $1980{ }^{27}$ But the nature and direction of the

\footnotetext{
22 Rai, supra note 1 , at 88.

23 Id. at 90 (citing MERTON, supra note 12, at 273 (discussing the proper behavior of a scientist)).

24 See e.g., JEROME R. RAVETZ, SCIENTIFIC KNOWLEDGE AND ITS SOCIALPROBLEMS 245 (1996). For more on the market for kudos, see infra notes 34-35, 68 and accompanying text.

$25 I d$. at 245-72 (reviewing the evolution of socially accepted practices for protecting this form of property in the scientific community including the present method of journal publication and citation thereto).

${ }^{26}$ Rai herself recognizes that scientists sought recognition and esteem under the prescriptive norms of the basic biological research community. Rai, supra note 1, at 90 .

27 According to Rai, recent changes in patent law caused changes in attitudes towards obtaining patents in basic biological research. Id. at 94 .
} 
causal link between prescriptive norms and changes in law are not clear in this area. The fact that few patents were obtained during the early days in molecular biology does not necessarily mean that they were not desired. Patents may not have been sought because, as Rai correctly points out, a number of hurdles to such patents existed as a matter of positive law during this time. $^{28}$ Many federal courts, including the Supreme Court, were hostile towards patents and promulgated a variety of limits on patentability, including an enhanced utility requirement and the treatment of algorithms as excluded from patentable subject matter. ${ }^{29}$ While positive law became more favorable to these types of patents, to the extent that the desire for patents preceded this change in the law, law can be viewed as having caught up with prescriptive norms, rather than as having spurred changes in them.

Furthermore, the breakdown in prescriptive norms that Rai attributes to patents in the post-1980 basic biological research community actually occurred well before 1980 as a result of several factors other than patents, which were largely unavailable in that community before 1980. Patents are not assigned any of the blame for the breakdown in the community of science that began long before 1980, in Jerome Ravetz's detailed account of the social problems in science after World War II. ${ }^{30}$ Instead, Ravetz ties this breakdown to what he terms the "industrialization of science." 31 By this he means the dominance of capital-intensive research and the concomitant reliance of science on government and industry for massive sums of money to fund this research. ${ }^{32}$ According to Ravetz, these changes brought a sudden increase in the size of the scientific community, which caused differentiation and stratification within the community. ${ }^{33}$ This in

\footnotetext{
28 The term "positive law" refers to the set of currently binding statutes, judicial decisions, and administrative rules. The term "normative law" includes accepted and theoretical principles about what those binding statutes, decisions, and rules should be.

29 See generally Donald S. Chisum, Craig Allen Nard, Herbert F. Schwartz, Pauline NEWMAN \& F. SCOTT KIEFF, PRINCIPLES OF PATENT LAW 729-812 (1998) (reviewing shifts in the positive law of utility and statutory subject matter). In preparation for his confirmation hearing as President Johnson's nominee to the Supreme Court, Thurgood Marshall reportedly responded to a question from a well-known Senator about his views on patents by saying: "I haven't given patents much thought, Senator, because I'm from the Second Circuit and as you know we don't uphold patents in the Second Circuit." Gerald Mossinghoff, The Creation of the Federal Circuit in CHISUM ET AL., supra, at 29-30. Similarly, as Rai recognizes, Justice Jackson noted a "strong passion in this Court for striking down [patents,] so that the only patent that is valid is one which this Court has not been able to get its hands on." Rai, supra note 1, at 102 n.133 (quoting Jurgenson v. Otsby \& Barton Co., 335 U.S. 560, 572 (1949) (Jackson, J., dissenting)).

30 RAVETZ, supra note 24 , at 30-68.

31 Id. at 30.

32 Id:; see also MARSHALL S. SHAPO, A NATION OF GUINEAPIGS7 (1979) (noting enormous growth in the number of scientists by 1979 and reporting an estimate "that about 85 percent of all the scientists who ever lived" were living at that time).

33 RAVETZ, supra note 24, at 30.
} 
turn caused a concentration of power to distribute kudos in small numbers of the most prestigious individuals and institutions. ${ }^{34}$

Frustration of the prescriptive norms should not be unexpected in such a stratified community engaged in a highly competitive market for kudos. ${ }^{35}$ Desire for recognition and prestige can function like desire for property in frustrating the prescriptive norms. By focusing so heavily on property, Rai glosses over the powerful role generally played by descriptive norms, sometimes called "regularities," which describe tendencies, habits, inclinations, proclivities, or preferences. ${ }^{36}$ Scientists are burdened with the same basic tendencies experienced by everyone. Some of these tendencies may be seen as relatively benign, such as the desire to like and to be liked by members of our communities. Other tendencies may be seen as more pernicious, such as ego, hubris, and desire for fame. Some may be seen as more ambiguous in their net impact, such as ambition and desire for $\mathfrak{x}$ complishment. In the context of science, these descriptive norms are manifested in the ways that scientists treat recognition and esteem, similar to the ways others treat more tangible forms of property.

The interaction between descriptive norms and prescriptive norms is complex. In some cases descriptive norms are the very devices that operate to make humans responsive to prescriptive norms. ${ }^{37}$ In other cases, descriptive norms are the very sources of frustration for prescriptive norms.

In the hypothetical case of a more-established scientist who is prestigious and closely associated with a particular theory, consider the possible frustrations of the prescriptive norms that might be wrought in a putative utopia of no patent property. ${ }^{38}$ The scientist may manifest various combinations of the many descriptive norms - benign, pernicious, and ambiguous. As an established and prestigious member of the academic community, this

${ }^{34} I d$. Kudos can take many forms, including publication in prestigious journals, citation by peers, general prestige, the award of research grants, academic appointments and tenure, and salary. Id. at 24572 (reviewing the evolution of the forms of kudos in the scientific community).

35 While kudos can function as a form of property, the markets for kudos differ from markets for other forms of property in important respects. Markets for kudos are especially complex, and while markets for kudos do involve transfers of money, such transfers in the kudos markets often do not involve ordinary market prices. As discussed below, markets for kudos are likely to have a greater propensity for failure than markets for other forms of property. See infra notes 68-69 and accompanying text.

36 See Robert D. Cooter, Decentralized Law for a Complex Economy: The Structural Approach to Adjudicating the New Law Merchant, 144 U.PA. L. REV. 1643, 1656-57 (1996) (contrasting use of the word norm to refer to an obligation rather than to a regularity in behavior).

37 For example, an individual's desire to be liked by the community may motivate individuals to behave in accordance with the prescriptive norms of the community. See Robert C. Ellickson, Law and Economics Discovers Social Norms, 27 J. LEGAL STUD. 537 (1998) (arguing that founders of classical law and economics implicitly placed too much stress on an individual's hunger for material, as opposed to status, rewards).

38 This hypothetical case is also useful for fully evaluating the relative performance of a state of the world in which patents are available in the basic biological research community and one in which they are not. See infra note 65 and accompanying text. 
scientist is likely to sit on committees that review applications for funding, manuscripts submitted to prominent journals for publication, and the candidacies of less-established scientists for promotion. In this hypothetical case, a less-established scientist with a competing theory who is aware of the descriptive norms and who is interested in funding, publishing, and obtaining promotion may rationally experience apprehension about offending the descriptive norms of the more-established scientist. The more-established scientist might even act in accordance with pernicious descriptive norms in a way that directly influences the less-established scientist's research agenda.

A resulting change in the research agenda of the less-established scientist could offend each of the prescriptive norms. For instance, such a change could offend the norm of independence-the less-established scientist's research agenda would have been influenced by something other than desire for scientific truth. Likewise, the norm of organized skepticism also would be offended if research into a competing theory were foregone. If the change in the less-established scientist's agenda embraced the moreestablished scientist's theory, and that theory happened to be wrong, then the norm of universalism would be offended because the less-established scientist would have subscribed to a theory precisely because of its proponent's personal attributes rather than its scientific truth. The disinterestedness norm would be offended because the less-established scientist would have selected a research agenda that would benefit the less-established scientist's career instead of the public storehouse of scientific knowledge. Further, the communism norm would be offended if limited resources were directed in a way that would benefit the two scientists rather than the public storehouse of scientific knowledge. Finally, the invention norm would be offended because the public storehouse of scientific knowledge would not have been enhanced.

Thus, the portrait painted by Rai of the early days of the basic biological research community is not the appropriate benchmark against which to measure the performance of the current patent system. The benchmark offered by Rai is a utopian vision characterized by specific prescriptive norms against intellectual property generally and patents in particular, but devoid of descriptive norms such as selfish behavior, which enjoys no frustration of the consensus set of abstract prescriptive norms.

This utopia, however, never existed. Contrary to Rai's assertion, it is not clear that the pre-1980 basic biological research community had a prescriptive norm specifically discouraging patents. In fact, the community did have a prescriptive norm that at least permitted, if not encouraged, seeking other forms of intellectual property, such as scientific kudos. Furthermore, descriptive norms such as selfish behavior have been, and remain, a significant presence in the real biological research community made up of real humans engaged in the highly competitive market for kudos. Descriptive norms have frustrated the prescriptive norms of the basic biological research community since long before the general availability of patents in that community. 
Indeed, it is not clear that any historical benchmark would be a proper basis for comparison against the present basic biological research community because the community has enjoyed such rapid and enormous advances in technology and overall prosperity, even since 1980. ${ }^{39}$ Rather, a proper evaluation of the impact patents have had on the basic biological research community requires a comparison of the present state of the world, where patents are available, with the realistic alternative state, which differs solely in that patents are not available. ${ }^{40}$ The operative questions explored below are whether the potential breakdown in prescriptive norms would be greater in one of these states of the world, and if so, in which one.

\section{MAKING A PROPER COMPARISON}

To compare properly the present state of the world where patents exist to the alternative state where patents do not exist, it is first necessary to understand the theory, design, and operation of the patent system. The focus of Rai's argument is a purported shift in patent theory from one that views patents as providing incentives for engaging in inventive activity to one that views patents as providing incentives for engaging in subsequent commercialization. ${ }^{41}$ There was no such shift. The changes in positive patent law discussed by Rai marked important components of a larger effort to help positive law catch up with normative theory and to bring the patent system more in line with its design.

As I explain at length in a separate paper, the key to understanding the intended operation of the patent system is to consider a normative theory that views patents as providing incentives for commercialization. ${ }^{42}$ According to the commercialization theory, the treatment of patents as property rights enforceable by property rules - as distinct from liability rules ${ }^{43}-$

39 See generally OfFICE OFTECHNOLOGY ASSESSMENT, BIOTECHNOLOGY IN A GLOBAL ECONOMY 133 (U.S. Government Printing Office, OTA-BA-495, Washington, DC, 1991) [hereinafter BIOTECHNOLOGY IN AGLOBALECONOMY] (reviewing changes in biotechnology, defined to be only the "new biotechnology," which refers to the recombinant DNA, cell fusion, and bio-processing techniques that did not come into regular use until around 1980, or thereafter); see also infra notes 54-59 and accompanying text.

40 For a proper comparison, the set of prescriptive norms discussed by critics of the patent system is assumed to be a constant, shared by both states of the world. The set of descriptive norms discussed above is also assumed to be a constant, shared by both states of the world. The relevant inquiry, then, is not whether a patent system has problems, but rather how it compares to other available alternative institutions. See Harold Demsetz, Information and Efficiency: Another Viewpoint, 12 J.L. \& Econ. 1, 14 (1969) (critiquing the so-called nirvana approach to institution analysis in favor of a comparative instit ution approach).

41 Rai, supra note 1, at 96-97.

42 F. Scott Kieff, Property Rights and Property Rules for Commercializing Inventions, 85 MINN. L. REV. 697.

43 An entitlement enjoys the protection of a property rule if the law condones its surrender only through voluntary exchange. The holder of such an entitlement is allowed to enjoin infringement. An entitlement has the lesser protection of a liability rule if it can be lost lawfully to anyone willing to pay some court-determined compensation. The holder of such an entitlement is only entitled to damages caused by infringement. See Guido Calabresi \& A. Douglas Melamed, Property Rules, Liability Rules, 
is necessary to facilitate investment and coordination around the complex, costly, and risky commercialization activities required to turn nascent $\dot{n}$ ventions into new goods and services. ${ }^{44}$ Thus, the power to restrict use that is conferred by a patentee's property right is paradoxically essential to avoiding underuse. Not only are property rights of exclusion advantageous, they must also be enforced by a property rule, not a liability rule. The use of liability rules would lead to a net increase in social cost and frustrate the very efforts for ordering and bargaining around patents that are necessary to generate output of patented inventions. ${ }^{45}$ Furthermore, the ability to use price discrimination gives the patentee a strong financial incentive to maintain output at competitive levels thereby avoiding the dead-weight loss potentially caused by a property owner's power over price. ${ }^{46}$

The commercialization view also shows how the changes in positive patent law discussed by Rai are improvements. For example, patents should be available for subject matter such as living organisms, gene fragments, computer software, and financial services, which many like Rai previously considered to be ineligible for patent protection. ${ }^{47}$ Protection is necessary to permit recovery of commercialization costs in markets such as these precisely because they are characterized by a particularly large difference between average cost and marginal cost. ${ }^{48}$ Indeed, the need for protection is especially strong in such markets because commercialization costs represent a significant component of average cost. ${ }^{49}$ Furthermore, the categories of patents in the field of basic biological research that Rai considers to be pernicious simply cannot, under applicable law, have the very broad impact she ascribes to them. For example, Rai raises the problem of patents on multiple gene fragments, such as ESTs, blocking the use of a larger DNA sequence of

and Inalienability: One View of the Cathedral, 85 HARV. L. REV. 1089 (1972); see also Jules L. Coleman \& Jody Kraus, Rethinking the Theory of Legal Rights, 95 YALE. L.J. 1335 (1986).

44 See Kieff, supra note 42, at 707-12 (showing how a patent right to exclude those who have not shared in the commercialization costs provides incentives for the patentee and other players in the complex process of technological progress to come together and incur such commercialization costs, thereby facilitating the social ordering and bargaining around inventions that are necessary to generate output in the form of information about the invention, a product of the invention, or a useful embodiment of the invention).

45 Id at $732-36$ (showing how the potential infringements induced by a liability rule will discourage investment in the commercialization process ex ante and may even result in a net destruction of social wealth if the collective costs of entry and exit across infringers exceeds the social surplus otherwise created by the invention).

${ }^{46} I d$. at 727-32 (showing how the patent system's facilitation of tie-ins and other forms of price discrimination where technological and economic factors alone might prevent price discrimination provides incentives for the patentee to elect to keep output at competitive levels).

47 Id. at $701 \mathrm{n} .9$ (collecting sources of criticism of present patentable subject matter); see also Rai, supra note 1, at 100-09 (criticizing the change in positive patent law regarding patentable subject matter).

${ }^{48}$ Kieff, supra note 42 , at 724-26, 747-48. Average cost per unit of output includes both a pro rata share of total fixed costs, like the costs of building a factory, and marginal costs, which are the incremental costs of inputs like raw materials and labor that are needed to make each unit of output.

49 Id. 
which they can be a part. ${ }^{50}$ As the law currently stands, a patent claim directed to a gene fragment like an EST cannot be construed to cover a larger DNA sequence, such as a substantial portion of an entire gene. ${ }^{51}$

In addition, according to the commercialization view of patents, these changes bring the present patent system in line with design. Although the commercialization view of the patent system had not been previously articulated, collective writings of those involved in framing our current patent system demonstrate that the commercialization theory's link among patents, property rights, and price discrimination informed and motivated their efforts to frame the system. ${ }^{52}$

The actual operation of the patent system presents an even greater obstacle for patent critics. Regardless of normative theory, the very real beneficial impact of patents in the basic biological research community evidences the enormous expansion of the entire biotechnology industry that has occurred since the 1980 changes in positive patent law discussed by Rai. The unique growth in the biotechnology industry in the United States has directly benefited both the basic biological research community, by providing expanded resources like funding; and the general public, by providing better goods and services in important industries like healthcare.

Critics of the use of patents in the basic biological research community must acknowledge the immense amounts, and diversity in sources, of funding and other resources that patents have brought to this community. A decade after the 1980 changes in positive patent law discussed by Rai, the United States continued to make the largest commitment to basic research in biological sciences worldwide. ${ }^{54}$ And by 1990 , the single largest source of funding for research and development in this field in the United States

50 See Rai, supra note 1, at 126-29 (citing Heller \& Eisenberg, supra note 2). ESTs are only small fragments of full-length genes. They are not usually useful in making the product that is encoded by the gene and instead are often used as tags, or markers, to identify whether a particular gene is present. Typically, the full-length gene, or a substantial portion of it, is needed to make the product encoded by that gene. For most pieces of DNA, their biological significance is due mostly to the product they encode.

51 See Kieff, supra note 42, at 721-22 (noting that if the patentee attempts to argue that the claim to the smaller fragment covers the fragment within the environment of the larger DNA, then the claim is likely to be held invalid over the prior art or for lack of adequate disclosure because to be valid, the claimed subject matter must be new and nonobvious, and the patent application must disclose the metes and bounds of the claimed subject matter with physical and chemical detail as well as how to make and use it; and alternatively pointing out that since ESTs exist in nature in the company of the other DNA of the genome, a typical EST claim must be limited in order to overcome this prior art to a version of the EST in some specific environment other than its natural one, such as isolated from all other DNA or inserted into an artificially engineered piece of DNA, and the details of the degree of isolation or of the engineered piece of DNA must also be provided so as to satisfy the disclosure requirements).

52 Id. at 736-46 (reviewing writings of the framers of the present patent system and showing the importance of the commercialization view of patents to the design of the system).

53 See Ian Cockburn et al., Pharmaceuticals and Biotechnology, in U.S. INDUSTRY IN 2000 STUDIES IN COMPETITIVE PERFORMANCE 389-92 (David C. Mowery ed., 1999) (reviewing relative performance of the United States biotechnology industry).

54 See BioteChNOLOGY IN A GlobAl ECONOMY, supra note 39, at 163. 
was private industry, not the federal government. ${ }^{55}$ According to a recent collection of studies by the National Research Council, the unique growth of biotechnology in the United States, as compared with other countries, is due largely to the link between industry and academic science that was facilitated by the same intellectual property laws that Rai discusses, which were implemented since 1980 in the United States but not in other countries. ${ }^{56}$ The study also credits these unique features of United States patent law for allowing the United States to make better comparative use of biotechnology as a research tool. ${ }^{57}$ Not surprisingly, many researchers and industrialists regard patent protection as the most important factor in preserving the United States's competitiveness in biotechnology. ${ }^{58}$ According to Dr. William Raub, then of the National Institutes of Health, "many biological scientists, perhaps most, regard the patent process as a means of institutionalized secrecy, whereas it is in fact a time-tested way to assure broad and ready access to proprietary information."59

Despite the unmatched growth of United States biotechnology industry and research since 1980, Rai criticizes any theory of the patent system that focuses on the development of nascent inventions, like the commercialization theory. ${ }^{60}$ Patent critics like Rai and Eisenberg argue that the patent right to exclude actually interferes with commercialization in the field of basic biological research and thereby frustrates the prescriptive norms. ${ }^{61}$ The patent right to exclude may allow a patentee of a basic research tool-like a particular cell line or DNA construct - to exert control over others interested in using those tools to conduct subsequent research. According to patent critics, the patent holder may elect to exercise such control in a way that will reduce total creative output "by refusing to license those who have different theoretical perspectives, or more generally, those who present a professional threat." ${ }^{, 62}$ Rai correctly points out that in such situations the potential social benefits of licensing are high but would not be realized through a voluntary

$55 I d$. at 164 (noting that despite growth in Federal Government funding for research and development since 1980, only since 1980 has industry spent more than the Federal Government on research and development).

56 See Cockburn, supra note 53, at 390-92.

57 Id. at 392-95.

58 See Europe Lags Behind in Biotech Commercialization?, BIOTECH. BUS. NEWS, Jan. 17, 1992; see also Reid Adler, Genome Research: Fulfilling the Public's Expectations for Knowledge and Commercialization, 257 SCIENCE 908, 909 (1992) (noting that the United States biotechnology industry is critically dependent on patent protection to maintain its leadership in world markets).

59 Commercialization of Academic Biomedical Research: Hearings Before the Subcomm. on Investigations and Oversight and the Subcomm. on Science, Research and Technology of the House Comm. on Science and Technology, 97th Cong. 79 (1981) (testimony of Dr. William Raub).

${ }^{60}$ Rai, supra note 1, at 120-29.

61 Id.; see also, e.g., Eisenberg, Progress of Science, supra note 2.

62 Rai, supra note 1, at 124 (citing Eisenberg, Progress of Science, supra note 2, at 1057-61). 
license agreement because they would inure to the benefit of the would-be licensee and society, but to the detriment of the would-be licensor. ${ }^{63}$

Such a refusal to license would offend the consensus set of prescriptive norms. The independence norm would be offended because the would-be licensee's research agenda would have been influenced by something other than the desire for scientific truth. Similarly, the norm of organized skepticism would be offended because research into a competing theory would have been foregone. The universalism norm would be offended because the would-be licensee's theory would have been abandoned not because of scientific merit, but rather because of the attributes of the would-be licensor. The norm of disinterestedness would be offended because the would-be licensee's theory would have been abandoned not for the benefit of public storehouse of scientific knowledge, but rather for the benefit of the wouldbe licensor's career. The norm of communism would be offended because failure to license would prevent society from realizing a potential benefit so as to prevent the would-be licensor from suffering a detriment. The invention norm would be offended because the would-be licensee's efforts would not come to fruition and enhance the public storehouse of scientific knowledge.

But such an account of this potentially bad outcome is not complete. The descriptive norms suggest that a patentee might be motivated to suppress subsequent work in order to avoid criticism or discredit. Alternatively, the descriptive norms also suggest that a patentee might respond to the prescriptive norm of organized skepticism and thereby be selfishly motivated to encourage subsequent work in the hope of obtaining peer confirmation and acceptance of the patentee's work and theories. The patentee may be motivated to have even large numbers of subsequent users by a desire for fame, which in academic circles may come in the form of a high number of citations to the scientist's publications describing the subject matter of the patent. ${ }^{64}$ The relative strengths of these competing motivations are unclear, but by failing to address one entire set, the patent critics fail to offer any reason why their net impact is expected to be negative.

Furthermore, the patent critics' evaluation of this potentially bad outcome fails to compare the patent regime with the alternative regime of no patent availability in view of the same motivations for suppression of subsequent work. Consider again the case discussed earlier of a prestigious, more-established scientist who is closely associated with a particular theory, and a less-established scientist with a competing theory, who is interested in funding, publishing, and promotion. ${ }^{65}$ The more-established scientist may be motivated to suppress subsequent work by the less-

63 Id.

${ }^{64}$ Citation analysis as a measure of kudos is not limited to science. Indeed, it is a topic of great interest to communities in other disciplines, including law. See, e.g., Symposium, Trends in Legal Citations and Scholarship, 71 CHI.-KENT L. REV. 743 (1996).

65 See supra note 38 and accompanying text. 
established scientist just like the patentee in Rai's example may be motivated to suppress. ${ }^{66}$ The availability of patent protection may provide the less-established scientist with sources of funding and promotion alternative to those guarded by the more-established scientist. With a patent obtained on some product or method tied to the competing theory, the lessestablished scientist can turn to the capital and industrial markets for funding or employment. It may be socially desirable for the less-established scientist's theory to be evaluated by those best able to do so. But while the capital and industrial market participants, themselves, may have less expertise in evaluating technical issues than the more-established scientist, they may be able to cover for this deficiency by hiring technical consultants. Furthermore, the market participants are less likely than the more established scientist to have cognitive and emotional biases in evaluating issues in the scientist's own technical field. Patents can therefore be necessary to allow the lessestablished scientist to further the consensus set of prescriptive norms.

Rai suggests that negotiations between a would-be licensee and a would-be licensor are likely to face valuation problems. ${ }^{67}$ Especially for patents in basic biological research, objective indications of value may be hard to find because full commercial markets may not yet have blossomed, and the patent holder might exhibit a cognitive bias towards overvaluation if the original inventor has not yet sold the patent. Valuation problems of this type can plague negotiations in any market. But, again, Rai fails to compare the potential for these problems to operate in the market characterized by patents on the one hand and the market characterized by kudos for scientific achievement on the other hand. Important differences between the two markets suggest that these problems will actually be worse in the market for scientific kudos. Kudos are not fungible, and the number of potential valuators in the kudos market is relatively small. ${ }^{68}$ In contrast, scientists are given unfettered access to the entire worldwide financial community through the patent market, and, as discussed above, this ability for patents to bring immense amounts of, and diversity in sources of, funding and other resources to the basic biological research community is recognized as a critical factor in the great success the community has enjoyed since $1980 .{ }^{69}$

Rai also advances the argument articulated by Eisenberg and Michael Heller that even if patentees are willing to license, the transaction costs of licensing patents in basic biological research will unduly tax and retard subsequent research. ${ }^{70}$ But the basic biology research process, like any process, can be viewed as one that requires inputs and generates outputs, and

\footnotetext{
66 Rai's example is discussed supra at note 62 and accompanying text.

67 Rai, supra note 1 , at 126.

68 See RAVETZ, supra note 24, at 30 (describing the market for scientific credit as one in which power to give desired credit is concentrated in small numbers of the most prestigious individuals and institutions).

69 See supra notes 53-59 and accompanying text.

${ }^{70}$ Rai, supra note 1, at 126-29 (citing Heller \& Eisenberg, supra note 2).
} 
experience shows that patents on inputs generally do not prevent the production of outputs. ${ }^{71}$

Thus, a comparison between the state of the world in which patents are available for basic biological research and one in which they are not suggests that the patent state of the world better promotes the consensus set of prescriptive norms. Just as the descriptive norms suggest that a patentee may be motivated to suppress subsequent work in order to avoid criticism or discredit, they also suggest that a patentee may be selfishly motivated to encourage subsequent work in the hope of obtaining peer confirmation and acceptance of the patentee's work and theories. In addition, the availability of patent protection for those who want to do subsequent work may alleviate harm otherwise caused by those who might withhold kudos in an attempt to suppress subsequent work. While all markets experience some extent of market failures and transaction costs, the relatively large number of participants and the fungibility that are characteristic of a patent market suggest that it is likely to function better than the corresponding market for kudos, which is significantly smaller and more subjective. The ability for patents to bring immense amounts of, and diversity in, sources of funding and other resources to the basic biological research community is recognized as a critical factor in the great success the community has enjoyed since 1980. In view of the superiority in promoting the consensus set of abstract prescriptive norms that is enjoyed by a state of the world in which patents are available as compared to one in which they are not, the basic biological research community would be better off with a specific prescriptive norm in favor of obtaining patents.

\section{CONCLUSION}

Rai and Eisenberg make important contributions by elucidating several problems that can potentially arise from patents in the field of basic biological research. But as shown above, many such problems would be paradoxically worse for that community if patents were not available at all. Patents increase community output simply by increasing input. Patents also increase community output by improving efficiency. Patents overcome the frustration of the community's prescriptive norms that would otherwise be caused by selfish behavior in a market for only scientific kudos.

While public coercion against obtaining patents in the form of new laws or prescriptive norms would prevent both beneficial effects of patents, many of the problems that Rai and Eisenberg associate with patents may be

71 See Kieff, supra note 42, at 720-21 (noting that entire industries have come and gone using scores of patented inputs and that even in the specific case of the basic biological research community, scientists routinely use a variety of patented machines, reagents, and equipment in the ordinary course of research; and pointing out that this argument also goes too far and would require that members of the basic biological research community should not have to pay the licensing fee for too many other patented inputs, including, for example, the intermittent windshield wiper subsystems on the cars they drive to the laboratory in the morning). 
avoided through selfish private action. Rai, herself, points out that universities such as MIT have developed patent acquisition and technology transfer practices that tend to maintain the tightest private control over the inventions that can be most efficiently utilized from a societal point of view if subject to a single rights-holder. ${ }^{72}$ This behavior is in the commercial self-interest of the universities because obtaining and enforcing patents in this area is an extremely expensive and risky investment. Rai's own account thereby shows the emergence of a new descriptive norm among individual actors in the community that avoids frustration of the consensus set of abstract prescriptive norms without public action to create and enforce a new, more specific prescriptive norm.

This result should not be surprising. Consider the ordinary practice among owners of prime real estate in the most expensive parts of Manhattan who rationally elect to license freely the public to use plazas and expanded sidewalks while simultaneously reserving uncluttered title to their land by relying on carefully placed anti-adverse possession plaques. ${ }^{73}$ Rather than implement new prescriptive norms or laws against patents, the community should rest assured that new descriptive norms that will emerge because individual community members acting rationally within their own self-interest will tend to maintain the tightest private control over only those inventions that can be most efficiently utilized if subject to a single rights-holder.

Certainly, this private action will be imperfect-holdouts and strategic behavior, for example, will continue-but the above discussion shows that it is better than the alternative of broad restrictions on patents publicly imposed by new laws or prescriptive norms. Recent actions by the governments of the United States and England show that even the mere suggestion of the unavailability of patents in the basic biological research community can cause a devastating reduction in the crucial sources of funding and other resources that the community enjoys from the private sector. ${ }^{74}$ Therefore, the public should not adopt Rai's prescription for the imposition of new prescriptive norms and laws to prevent the use of patents in the basic biological research community.

\footnotetext{
72 Rai, supra note 1, at 112-13 (describing practices); id. at 145 (noting practices to be efficient).

73 These metal plaques implanted in the sidewalks usually state that the real estate is the property of a private landowner and that permission is granted for members of the public to make limited use of it, but that such permission is revocable at the sole discretion of the owner. The assertion of ownership combined with a grant of permission prevents anyone else from acquiring title through adverse possession or an easement by prescription. All of this is accomplished without costly and obtrusive fences, thereby leaving the thoroughfares of a very crowded city relatively open to the flow of pedestrian traffic.

74 See Robert Langreth \& Bob Davis, Press Briefing Set Off Rout in Biotech, WaLL ST. J., Mar. 16, 2000, at A19 (reviewing aftermath of announcements by the President of the United States and the Prime Minister of England that stock markets understood to be signals that both countries would not allow patents on the results of the human genome project); see also Robert Langreth \& Ralph T. King Jr., Biotechnology, Genomics Stocks Plunge on Fear U.S. May Curb Gene-Data Sales, WALL ST. J., Mar. 15, 2000, at A3 (reporting announcement and initial market reaction).
} 
NORTHWESTER N UNIVERSITY LAW REVIEW 